\title{
PROFIL PENDIDIKAN KARAKTER SD CREATIVE KECAMATAN KARANGAN KABUPATEN TRENGGALEK
}

\author{
Eries Norma Yusmita ${ }^{1)}$,Asri Kusumaning Ratri ${ }^{2)}$ \\ ${ }^{1)}$ STKIP PGRI Tulungagung, ${ }^{2}$ STKIP PGRI Tulungagung \\ ${ }^{1)}$ email:eriesnorma@gmail.com, ${ }^{2)}$ asri_aci_ratri_@yahoo.co.id
}

\begin{abstract}
Abstrak
Pendidikan karakter sejak lama dilaksanakan di SD Creative dan SD Creative menjadi salah satu sekolah favorit di Kecamatan Karangan. Penelitian ini bertujuan untuk: (1) mendeskripsikan persiapan pelaksanaan pendidikan karakter di SD Creative (2) mendeskripsikan pelaksanaan pendidikan karakter di SD Creative (3) mendeskripsikan evaluasi pendidikan karakter di SD Creative (4) mendeskripsikan hambatan yang dialami SD Creative dalam penanaman karakter siswa. Penelitian ini merupakan penelitian kualitatif dengan pendekatan deskriptif. Sumber data, yaitu guru kelas II dan IV, kepala sekolah, pembina ekstrakurikuler, siswa kelas II dan IV. Penelitian dilakukan pada tahun ajaran 2017/2018. Teknik pengumpulan data menggunakan observasi, wawancara mendalam, analisis dokumen. Intrumen yang digunakan yaitu panduan observasi, panduan dokumentasi, dan lembar wawancara. Pengecekan keabsahan data menggunakan ketekunan pengamatan, perpanjangan kehadiran peneliti, dan triangulasi. Hasil penelitian menunjukkan (1) perencanaan pelaksanaan pendidikan karakter dirancang melalui program kegiatan sekolah dan RPP (2) kegiatan di SD Creative sudah tercermin penanaman karakter, namun 18 nilai karakter belum tentu ada pada setiap kegiatan. Pelaksanaan pendidikan karakter dilaksanakan melalui pelaksanaan pembelajaran, kegiatan spontan, kegiatan rutin, ekstrakurikuler (3) evaluasi pendidikan karakter melalui pertemuan beberapa dilakukan satu bulan sekali oleh pihak yang bersangkutan (4) ada beberapa hambatan di dalam maupun di luar kelas pada pelaksanaan kegiatan pendidikan karakter.
\end{abstract}

Kata Kunci: profil, pendidikan karakter, sekolah dasar 


\begin{abstract}
Character education has long been carried out at SD Creative and SD Creative as one of the favorite schools in Karangan District. This study aims to: (1) describe the preparation of the implementation of character education at SD Creative (2) describe the implementation of character education at SD Creative (3) describe the evaluation of character education at SD Creative (4) describe the obstacles experienced by SD SD in planting the character of students. This research is a qualitative research with a descriptive approach. Data sources, namely class II and IV teachers, school principals, extracurricular coaches, class II and IV students. Research is carried out in the 2017/2018 school year. Data collection techniques using observation, indepth interviews, document analysis. The instruments used are observation guide, documentation guide, and interview sheet. Checking the validity of the data using persistence of observation, extension of the presence of researchers, and triangulation. The results showed that (1) the planning of character education was designed through school activity programs and RPP (2) activities at SD Creative had reflected the character planting, but 18 character values did not necessarily exist in each activity. The implementation of character education is carried out through the implementation of learning, spontaneous activities, routine activities, extracurricular activities (3) evaluation of character education through several monthly meetings conducted by the parties concerned (4) there are some obstacles inside and outside the classroom in the implementation of character education activities
\end{abstract}

Keywords: profile, character education, elementary school

\section{PENDAHULUAN}

Pendidikan merupakan wahana untuk mengembangkan watak dan membentuk kemampuan serta peradaban kehidupan bangsa yang bermartabat dalam rangka mencerdaskan kehidupan bangsa. Pasal 3 UU Sisdiknas menyebutkan, "Pendidikan nasional berfungsi untuk membentuk dan mengembangkan watak serta peradaban bangsa yang memiliki martabat dalam rangka mencerdaskan kehidupan bangsa, bertujuan untuk mengembangkan potensi peserta didik supaya menjadi manusia yang beriman dan bertakwa kepada Tuhan Yang
Maha Esa, berakhlak mulia, Creative, sehat, berilmu, mandiri, cakap, ‘dan menjadi seorang warga negara yang bertanggung jawab serta demokratis".

Banyak ditemui masalah moral yang terdapat dalam diri siswa sekolah dasar. Hal ini ditandai dengan perilaku siswa yang biasa terlambat masuk sekolah maupun masuk ke kelas setelah jam istirahat, bersikap kasar kepada teman, menyontek, berkelahi dengan teman, mengolok-olok sesama teman, corat-coret kursi dan bangku sekolah, tidak menjaga kebersihan kamar mandi sekolah, 
membeda-bedakan dan memilih-milih teman, merusak fasilitas yang ada di sekolah seperti perpustakaan dan taman, tidak mengenakan seragam sesuai dengan ketentuan, membuang sampah di sembarang tempat, dan tidak ada sikap sopan kepada guru.

Menurut Akbar (2011: 1-2) Praktik kegiatan pembelajaran nilai dan karakter di Sekolah Dasar kurang sesuai teori pembelajaran nilai dan karakter secara benar, kultur sekolah dirasakan kurang kondusif untuk pelaksanaan pendidikan nilai dan karakter, dan adanya perilaku siswa sekolah dasar yang berbuat seenaknya sendiri dan kurang memperhatikan aturan. Persoalan di atas terjadi karena kegiatan pendidikan yang cenderung mengabaikan aspek sikap dan cenderung overcognitive, akibatnya banyak siswa yang pintar atau berpengetahuan tetapi kurang mau melakukan apa yang dia ketahui karena aspek sikapnya atau karakter yang ada dalam dirinya kurang terbangun dengan baik.

SD Creative merupakan SD yang terhitung belum lama berdiri tetapi sudah menjadi sekolah favorit di Kecamatan Karangan yang juga melaksanakan penanaman pendidikan karakter. Hal ini dapat dilihat dari hasil observasi yang peneliti lakukan pada saat pelaksanaan kegiatan sehari-hari siswa SD Creative.
Siswa telah melaksanakan kegiatan pembiasaan pendidikan karakter yang berkaitan dengan sikap/afektif dan juga pada dokumen kegiatan pembelajaran mencantumkan karakter-karakter yang ingin dicapai serta tertulis tentang rencanarencana sekolah yang akan dilakukan. Selain itu juga penataan fisik sekolah yang sarat akan nilai dan nyaman ditempati peserta didik, fasilitas yang cukup baik, yakni berupa mushola, perpustakaan dengan koleksi buku yang cukup lengkap, dan hak aman untuk kegiatan bermain siswa. Selain itu siswa SD Creative juga memiliki prestasi yang membanggakan baik di tingkat kecamatan dan kabupaten.

Menurut Lickona, (dalam Akbar, 2011) Character consist of operative value, value in action. Untuk membangun watak positif, perlu suatu bentuk pengembangan secara seimbang dan berkelanjutan antara knowing the good, desiring the good, dan doing the good. Pendidikan karakter dikatakan berhasil jika terjadi keseimbangan antara pengetahuan tentang karakter baik, biasa merasakan karakter baik, dan melakukan suatu karakter yang baik.

Tujuan pendidikan karakter yaitu mengembangkan karakter positif manusia yakni akhlak yang mulia tidak hanya di lingkungan sekolah tetapi juga dilakukan di lingkungan keluarga serta lingkungan 
masyarakat dengan proses pendidikan yang melibatkan aspek afektif, aspek kognitif, dan aspek psikomotor sehingga akhlak mulia tersebut sesuai dengan UUD 1945 dan Pancasila. Munir (dalam Akbar, 2010:8) menyebutnya pendidikan karakter bertujuan menumbuhkan karakter positif (memperlemah karakter yang buruk dan memperkuat karakter yang baik). Karakter positif adalah karakter yang dikendalikan oleh nilai kebaikan yang diyakini, dengan keyakinan itulah siswa akan berperilaku, bersikap, bertutur kata, dan berbuat baik.

Puskurbuk (2010; 8-9) ada 18 nilai yang telah ditetapkan dan akan dikembangkan untuk peserta didik melalui pendidikan karakter. Nilai-nilai tersebut adalah Religius, Jujur, Toleransi, Disiplin, Kerja Keras, kreatif, Mandiri, Demokratis, Rasa Ingin Tahu, Menghargai Prestasi, Cinta Tanah Air, Cinta Damai, Semangat Kebangsaan, Bersahabat/ Komunikatif, Peduli Lingkungan, Gemar Membaca, Tanggung jawab, dan Peduli Sosial. Sedangkan prinsip-prinsip yang digunakan untuk pengembangan pendidikan karakter dalam Puskurbuk (2010: 11-12) yaitu pendidikan karakter harus disisipkan melalui semua mata pelajaran, dilaksanakan secara berkelanjutan, pendidikan karakter harus nilai tidak diajarkan tapi juga harus dikembangkan, proses pendidikan untuk pelaksanaan pendidikan karakter harus dilakukan peserta didik secara menyenangkan dan aktif.

Pelaksanaan pendidikan karakter di dalam Puskurbuk (2011: 11-12 ), satuan pendidikan harus melibatkan seluruh warga di lingkungan satuan pendidikan tersebut, seperti seluruh warga sekolah, orangtua siswa, dan masyarakat sekitar. Apabila seluruh warga sekolah dan semua pihak yang terlibat dalam pelaksanaan pendidikan berjalan bersama, maka pelaksanaan pendidikan karakter akan berjalan sesuai dengan nilai dan prinsipprinsip yang yang dilaksanakan. Pelaksanaan pendidikan Pembelajaran kontekstual yang mendukung pelaksanaan pendidikan karakter dalam Puskurbuk (2011:8) mencakup beberapa strategi, yaitu: (a) pembelajaran berbasis masalah (PBM), (b) pembelajaran berbasis proyek, (c) pembelajaran kooperatif (kelompok), (d) pembelajaran pelayanan, dan (e) pembelajaran berbasis kerja. Kelima strategi tersebut dapat memberikan nurturant effect pada pengembangan karakter peserta didik, seperti: karakter berpikir terbuka, tanggung jawab, cerdas, dan rasa ingin tahu.

Pada penelitian ini terkemuka beberapa alasan penelitian antara lain banyak ditemui masalah moral yang terdapat dalam diri siswa sekolah dasar, 
pelaksanaan penanaman pendidikan karakter yang dilaksanakan di sekolah dasar, hambatan yang dialami dalam mengembangkan pendidikan karakter. Sehingga penelitian ini berfokus pada Gambaran atau deskripsi fakta di SD Creative tentang pelaksanaan pendidikan karakter yang diselenggarakan, dan gambaran atau deskripsi fakta yang dialami oleh pihak SD Creative tentang perencanaan, pelaksanaan, evaluasi, serta hambatan dalam mengembangkan pendidikan karakter baik pada peserta didik.

\section{METODE PENELITIAN}

Penelitian yang digunakan yaitu jenis kualitatif. Penelitian ini bersifat deskriptif karena mendeskripsikan peristiwaperistiwa yang terjadi di lapangan secara riil. Penggunaan penelitian kualitatif ini dimaksudkan agar peneliti dapat mengetahui serta mendeskripsikan secara rinci dan jelas tentang pelaksanaan penanaman dan pengembangan pendidikan karakter di SD Creative. Penelitian ini difokuskan pada perencanaan, pelaksanaan, evaluasi, dan hambatan pelaksanaan pendidikan karakter di SD Creative.

Penelitian ini dilaksanakan di SD Creative di Kecamatan Karangan Kabupaten Trenggalek. SD Creative ini merupakan SD yang baru berdiri tetapi sudah menjadi salah satu favorit di Kecamatan Karangan dan juga sudah melaksanakan pendidikan karakter. Sumber data dalam penelitian ini adalah berupa situasi wajar (tanpa rekayasa) dan alamiah, dimana data tersebut dijabarkan dalam bentuk foto, catatan lapangan, hasil wawancara baik dari kepala sekolah, guru, peserta didik, maupun wali peserta didik, rekaman video (saat pembelajaran di kelas, di luar kelas, kegiatan lain yang dilakukan guru, peserta didik, kepala sekolah,), dokumen resmi dari pihak sekolah.

Teknik pengumpulan data dalam penelitian ini yaitu wawancara mendalam, pengamatan partisipasi (participation observation), dan analisis dokumen. Penyajian data yang dilakukan oleh peneliti adalah dengan menjadikan satu semua informasi yang telah didapat baik data hasil observasi, wawancara, dan dokumentasi untuk rumusan masalah yang pertama dan menarik suatu kesimpulan sementara. Jika setiap rumusan masalah telah mendapatkan kesimpulan akhir. Kesimpulan-kesimpulan inilah yang dinamakan temuan dalam penelitian, dan akan dijadikan sebagai hasil penelitian. Peneliti melakukan pengecekan keabsahan data dengan ketekunan pengamatan, memperpanjang kehadiran peneliti, dan melakukan triangulasi. 


\section{HASIL DAN PEMBAHASAN}

Persiapan pelaksanaan pendidikan karakter di SD Creative terdapat dua kegiatan. Kegiatan yang pertama yaitu pada intrakurikuler. Kegiatan intrakurikuler dilaksanakan di dalam kelas dengan menggunakan acuan Rencana Pelaksanaan Pembelajaran (RPP). Kegiatan kedua yaitu kegiatan ekstrakurikuler yang dilaksanakan di luar kelas menggunakan acuan program kegiatan ekstrakurikuler. Kegiatan sekolah di SD Creative dalam melaksanakan pendidikan karakter ada 3 kegiatan. Kegiatan tersebut antara lain kegiatan keteladanan, spontan, dan rutin.

Contoh kegiatan keteladanan yaitu antri mengaji kepada guru, mengaji secara individu dan berurutan, melaksanakan $3 \mathrm{~S}$ (salam, sapa, dan salaman), membersihkan sampah yang ada di lantai ruang kelas, menyeberang jalan secara hati-hati yang dibantu oleh satpam. Contoh kegiatan spontan di SD Creative yaitu membersihkan ruang kelas dan teras sesuai dengan jadwal piket, gotong royong merapikan bangku sebelum bel masuk berbunyi, melepas dan memakai sepatu dengan rapi,membuang sampah ditempatnya, makan snack bersama-sama ketika jam istirahat, bermain secara bersama-sama waktu istirahat. Contoh kegiatan rutin yaitu melaksanakan kegiatan
GISS (Gerakan Infaq Sehari Seribu) dan GISEL (Gerakan Infaq Sehari Lima ribu), belajar mengaji di kelas, melaksanakan literasi sebelum memulai pembelajaran, berdoa bersama-sama, melaksanakan jargon bersama-sama.

Evaluasi di SD Creative dilakukan rutin setiap akhir bulan melalui pertemuan rutin yang dihadiri kepala sekolah, seluruh pendidik, dan pihak yayasan. Evaluasi tersebut dibagi menjadi 2, yaitu evaluasi sekolah dan kelas, yang kedua evaluasi untuk setiap mata pelajaran. Sebelum pertemuan dilaksanakan, pendidik dan kepala sekolah mengumpulkan buku catatan harian siswa yang berisi catatan tertentu dari sikap peserta didik sehari-hari maupun dari wali murid agar permasalahan dapat terkumpul dan dapat terselesaikan secara bersama.

Pelaksanaan pendidikan karakter di SD Creative mengalami beberapa hambatan dari lingkungan sekolah maupun siswa itu sendiri. Hambatan pendidikan karakter tidak hanya terjadi pada intrakurikuler saja, namun juga ada hambatan kegiatan ekstrakurikuler. Hambatan pada kegiatan intrakurikuler yaitu ketika melaksanakan berdoa, siswa ditengah-tengan melantunkan doa, mereka terkadang lupa sampai mana/lanjutan dari bacaan doa tersebut. Seusai berdoa, siswa duduk kembali untuk melaksanakan 
kegiatan literasi yang dilaksanakan selama 10 menit, namun masih ada beberapa siswa yang masih gaduh dengan teman sampingnya. Hambatan yang terjadi ketika melaksanakan infaq kelas yaitu beberapa siswa tidak tertib untuk antri melaksanakan infaq, ada juga yang sulit berinfaq, beberapa siswa yang berinfaq dengan nominal ung yang besar, mengambil kembalian dengan menyerobot mengambil sendiri uangnya dengan tidak tertib tidak meminta kepada bendahara kelas sehingga membuat kelas sedikit gaduh.

\section{KESIMPULAN}

Hasil penelitian tentang pelaksanaan pendidikan karaker SD Creative Kecamatan Karangan Kabupaten Trenggalek yang telah disebutkan di atas, dapat disimpulkan bahwa persiapan pelaksanaan pendidikan karakter menggunakan RPP dan program kegiatan. Kegiatan sekolah di SD Creative dalam melaksanakan pendidikan karakter ada tiga kegiatan. Kegiatan tersebut antara lain kegiatan spontan, keteladanan, dan rutin. Evaluasi di SD Creative dilakukan rutin setiap akhir bulan melalui pertemuan rutin yang dihadiri seluruh pendidik, kepala sekolah, dan pihak yayasan. Hambatan yang ada pada kegiatan pendidikan karakter yaitu ada disetiap kelas, namun setiap kelas mengalami hambatan yang berbeda-beda.

\section{UCAPAN TERIMAKASIH}

Uapan terimakasih peneliti sampaikan kepada Direktorat Jenderal Penguatan Riset dan Pengembangan Kementerian Riset,Teknologi, dan Pendidikan Tinggi

\section{DAFTAR PUSTAKA}

Akbar, Sa'dun. 2010. Pengembangan Model-model Pendidikan Karaker Berbasis Nilai-nilai Kehidupan di Jawa Timur, fokus Uji Coba Model Skala Terbatas. Penelitian Mandiri. Malang: UM

Akbar, Sa'dun. 2011. Revitalisasi Pendidikan Karakter di Sekolah Dasar, Teks Pidato Pengukuhan Guru Besar dalam bidang Ilmu Pendidikan/Pendidikan Dasar. 8 Juni, Malang:UM

Aqip, Zainal dan Sujak. 2011. Panduan dan Aplikasi Pendidikan Karakter. Bandung: Yrama Widya

\section{Pedoman Pelaksanaan Pendidikan} Karakter. 2011. Pusat Kurikulum dan Perbukuan. (Online), (http://gurupembaharu.com), diakses 5 Maret 2016) 
Pengembangan Pendidikan Budaya dan Karakter Bangsa. 2010. Pusat Kurikulum dan Perbukuan. (Online), (http:

//tendik.kemendiknas.go.id),

diakses 5 Maret 2016八

Satori, Djam'an dan Komariah, Aan. 2010.
Sugiyono. 2007. Memahami Penelitian Kualitatif. Bandung: Alfabeta

Yuniarti, Lusi. 2011. Profil Pelaksanaan Pembelajaran di Kelas 1 Sekolah Dasar Negeri Percobaan Malang. Skripsi tidak diterbitkan. Malang: PPs UM.

Metodologi Penelitian Kualitatif.

Bandung: Alfabeta 